UDC 66.067.8.081.3

\author{
L.V. Sysa, K.V. Stepova, M.A. Petrova, A.Z. Kontsur
}

\title{
MICROWAVE-TREATED BENTONITE FOR REMOVAL OF LEAD FROM WASTEWATER
}

\author{
Lviv State University of Life Safety, Lviv, Ukraine
}

\begin{abstract}
Clay-based materials are promising adsorbents for removal of various pollutants from wastewater. This work is aimed to study the changes in structure and adsorption capacity of microwave-treated bentonite after adsorption of lead(II) ions. The structural investigation of the microwave-treated sample reveals that a partial destruction of silica skeleton takes place, and new surface nucleation centers are formed during microwave processing. The adsorption of $\mathrm{Pb}^{2+}$ on natural bentonite occurs on heterogeneous adsorption sites, whereas the removal of lead on microwave-treated sample is accompanied by the formation of plumbophyllite microcrystals. The natural and microwave-treated adsorbents were tested for lead adsorption in batch experiments. The results were fitted according to Langmuir, Freundlich, Toth, Redlich-Peterson, and Langmuir-Freundlich isotherms of adsorption. The microwave-treated samples revealed substantially higher efficiency towards the removal of lead, their maximal adsorption capacity was $114.7 \mathrm{mg} \mathrm{g}^{-1}$, whereas natural samples showed only $31 \mathrm{mg} \mathrm{g}^{-1}$.
\end{abstract}

Keywords: modified clays; bentonite; microwave treatment; adsorption isotherms; nonlinear modeling; lead removal.

DOI: $10.32434 / 0321-4095-2019-126-5-126-134$

\section{Introduction}

Industrial production implies extensive use of different natural resources, including water. As a result, large volumes of wastewater are formed. Water pollution caused by heavy metals is an important environmental concern due to its negative impact on public health. Heavy metals present in aquatic systems are toxic and prone to bioaccumulation. Consumption of contaminated water is one of the main exposure pathways of heavy metals to human body. Hence, the issue of wastewater treatment is of particular concern for the modern science.

Lead and its compounds come from numerous sources, such as electroplating, manufacturing of batteries, etc. It is especially dangerous to the health of pregnant women and children of all ages. Lead can accumulate in bone deposits, causing arthritis and arthrosis. Getting into the blood flow, lead may result in low hemoglobin levels or a decrease in red blood cells. Finally, there is an impact on the organs responsible for metabolism causing serious diseases that can lead to serious consequences, even death. At the same time, water treatment of lead deposits is a rather complicated process. Most of existing methods of heavy metals removal, such as chemical precipitation, ion exchange, electrolysis and reverse osmosis, are often neither effective nor economical [1]. The main requirements for the wastewater treatment are as follows: high recovery rate, the absence of secondary pollution, cost-efficiency, and simple application technology. The adsorption process fulfills the above-mentioned requirements. Sorbents based on clay minerals are widely used in various industries: wastewater treatment, food industry, pharmaceutical and cosmetic products, etc. Natural adsorbents are of special interest for treatment of various wastewaters from heavy metals $(\mathrm{Pb}, \mathrm{Cu}$, $\mathrm{Zn}, \mathrm{Cd}$, etc.), radioactive components and biological pollutants. Clay minerals (including bentonite) are cost-effective sorbents due to their natural abundance and low price, although their sorption characteristics are somewhat lower in comparison with synthetic materials. The pre-activation of clay sorbents improves their sorption activity [2]. For this purpose, hydrothermal cleaning, calcination, soda solutions, inorganic acids, organo-mineral composites and various types of irradiation are used [3]. In recent decades, the use of microwave radiation was 
developed as a promising way for preliminary treatment of sorbents. Studies have been carried out on synthetic sorbents (activated carbon, ion exchange resins, etc.) and on natural clays [4]. As a rule, in such cases, the combined activating effect of several factors is used: the addition of mineral acids, and heating and microwave irradiation. In present work, the activation of clay mineral was performed under microwave irradiation without adding acids or other activators. The adsorption capacity of treated bentonite in lead-containing solutions was studied.

\section{Experimental}

Materials

The raw material used for investigation was commercial bentonite purchased in a trading network in Ukraine $(\mathrm{pH}$ of aqueous extract was 8.92; bulk density was $1244 \mathrm{~kg} / \mathrm{m}^{3}$; and swelling rate was 2). It was ground to obtain powder and applied without any other treatment.

To produce microwave treated bentonite (MTB), one gram of initial bentonite was dispersed in $25 \mathrm{ml}$ of bidistilled water. Then, it was placed in a microwave oven and irradiated at $790 \mathrm{~W}$ for $20 \mathrm{~min}$. After sedimentation, the water was carefully decanted. The sample was dried at $80^{\circ} \mathrm{C}$ until the constant weight was reached.

A microwave generator was designed by the authors and assembled using a M-10 magnetron. The standard switching circuit was used (without pulse modulation); the radiation range was $2.45 \mathrm{GHz}$ with the output power of $790 \mathrm{~W}$. The horn antenna was applied for better distribution and concentration of radiation.

\section{Methods}

Atomic absorption spectrophotometer AAC115-M-1 was used for determination of $\mathrm{Pb}^{2+}$ content.

$\mathrm{X}$-ray diffraction measurements were conducted using standard powder diffraction procedure. Powder $\mathrm{X}$-ray diffraction patterns were recorded by using a DRON-3 diffractometer $\left(\mathrm{CuK}_{\alpha}\right.$, step size of $0.01^{0}$, counting time per step of $2 \mathrm{~s}$ ). The qualitative phase composition was determined by indexing the peaks of the corresponding minerals using FM-MINERAL software.

Scanning electron microscopy images together with EDX spectra were obtained by means of a Scanning Electron Microscope-Microanalyzer PEMMA-102-02 (JSC Selmi, Ukraine). EDS detection limit was of 10-100 ppm.

Fourier transformed infrared spectroscopy (FTIR) spectra were recorded using a NICOLET IS 10 spectrometer with a DTGS detector in attenuated total reflection (ATR) mode over the range from 650 to $4000 \mathrm{~cm}^{-1}$, the scan resolution was $4 \mathrm{~cm}^{-1}$.
The sorption properties of bentonite were studied under static conditions. A stock solution of lead nitrate was prepared from dry $\mathrm{Pb}\left(\mathrm{NO}_{3}\right)_{2}$ and bidistilled water. The working solutions were prepared from the stock solution by multiple dilutions with bidistilled water. The samples of bentonite $(1 \mathrm{~g})$ were added to simulated wastewater $(250 \mathrm{ml})$ and exposed to microwave irradiation at $790 \mathrm{~W}$ for $20 \mathrm{~min}$. The suspension was mixed and left to settle, and the procedure was repeated three times. The contact time was 24 hours. The concentration of $\mathrm{Pb}^{2+}$ ions was determined by the atomic absorption method. All the experiments were performed in triplicate.

Adsorption capacity was calculated based on a decrease of $\mathrm{Pb}^{2+}$ ions content in solution as follows:

$q_{e}=\left(C_{i}-C_{e}\right) \cdot \frac{V}{m}$,

where $\mathrm{q}_{\mathrm{e}}$ is the equilibrium adsorption capacity, $\mathrm{mg} / \mathrm{g}$; $\mathrm{V}$ is the volume of the solution, $\mathrm{ml} ; \mathrm{m}$ is the weight of the dried adsorbent, $\mathrm{g} ; \mathrm{C}_{\mathrm{i}}$ and $\mathrm{C}_{\mathrm{e}}$ are the concentrations of $\mathrm{Pb}^{2+}$ in solution before and after adsorption (initial and equilibrium), respectively.

The experimental results were fitted with Langmuir, Freundlich, Redlich-Peterson, Toth, and Langmuir-Freundlich isotherms of adsorption [5]:

- Langmuir:

$\mathrm{q}_{\mathrm{e}}=\frac{\mathrm{q}_{\mathrm{m}} \mathrm{KC}_{\mathrm{e}}}{1+\mathrm{KC}_{\mathrm{e}}} ;$

where $\mathrm{q}_{\mathrm{m}}$ is the maximal adsorption capacity, $\mathrm{mg} / \mathrm{g}$; $\mathrm{K}$, $\mathrm{a}$, and $\mathrm{n}$ are the isotherm constants;

- Freundlich:

$\mathrm{q}_{\mathrm{e}}=\mathrm{KC}_{\mathrm{e}}^{1 / \mathrm{n}}$

- Redlich-Peterson:

$\mathrm{q}_{\mathrm{e}}=\frac{\mathrm{KC}_{\mathrm{e}}}{1+\mathrm{aC}_{\mathrm{e}}^{\mathrm{n}}} ;$

- Toth:

$q_{e}=\frac{q_{m} a_{e}}{\left(1+a C_{e}^{n}\right)^{1 / n}} ;$

- Langmuir-Freundlich:

$q_{e}=\frac{q_{m}\left(K C_{e}\right)^{n}}{1+\left(K C_{e}\right)^{n}}$ 
The surface of the adsorbent is heterogeneous, and thus adsorption proceeds via a mixed mechanism. The aim of adsorption isotherms fitting is to establish an isotherm model that well describes the experimental data, and thus to determine the prevalent adsorption mechanism. The most commonly applied isotherms are known to be Langmuir, Freundlich, Redlich-Peterson, and Toth ones. Langmuir's theory suggests that all the adsorption sites are equivalent, and the distribution of the adsorbate is uniform [5]. According to Freundlich's theory, the surface is not homogenous, and therefore the adsorbate molecules are distributed non-uniformly [5]. The combination of Langmuir and Freundlich (Langmuir-Freundlich) isotherm and Redlich-Peterson isotherm typically represent the adsorbents with low- and high-energy sites [6]. The Toth isotherm is fitted well with the data of adsorbents with low-energy sites.

The isotherms were fitted using the gradient descent fitting method performed by Python programming code. The adsorption parameters were selected by minimizing the average relative error (ARE) [7]:

$$
\frac{100}{\mathrm{n}} \sum_{\mathrm{i}=1}^{\mathrm{n}}\left|\frac{\mathrm{q}_{\mathrm{e}_{\_} \text {exp }}-\mathrm{q}_{\mathrm{e} \_ \text {calc }}}{\mathrm{q}_{\mathrm{e} \_ \text {exp }}}\right| \text {, }
$$

where $\mathrm{q}_{\mathrm{e} \text { exp }}$ and $\mathrm{q}_{\mathrm{e} \text { calc }}$ are the experimental and calculated adsorption capacities, respectively; $n$ is the number of the experimental points.

The optimal model was selected by performing the following steps. Two experimental measurements were assigned to test points and not used for isotherms fitting. For each model, the isotherm parameters were calculated by minimizing the ARE. The models were validated by calculation of ARE for test points. The best-fit isotherms were selected based on the value of test points errors and used to establish the adsorption mechanism and calculate the maximal adsorption capacity, where appropriate. The values of determination coefficients $\left(\mathrm{R}^{2}\right)$ are presented as reference because they are typically used in similar studies $[1,8]$. However, the use of determination coefficients as the main metric for isotherm selection can cause ambiguous results.

\section{Results and discussion}

\section{Characterization of materials}

Quartz, montmorillonite, chlorite and mica were identified as crystalline phases for natural bentonite, that observation agreed well with our previous work [9]. However, new reflections appeared after adsorption (Fig. 1). They were indicated as plumbophyllite, $\mathrm{Pb}_{2} \mathrm{Si}_{4} \mathrm{O}_{10}\left[\mathrm{H}_{2} \mathrm{O}\right]$ [10]. It means that the formation of microcrystals of individual compound of poorly soluble polysilicate occurred
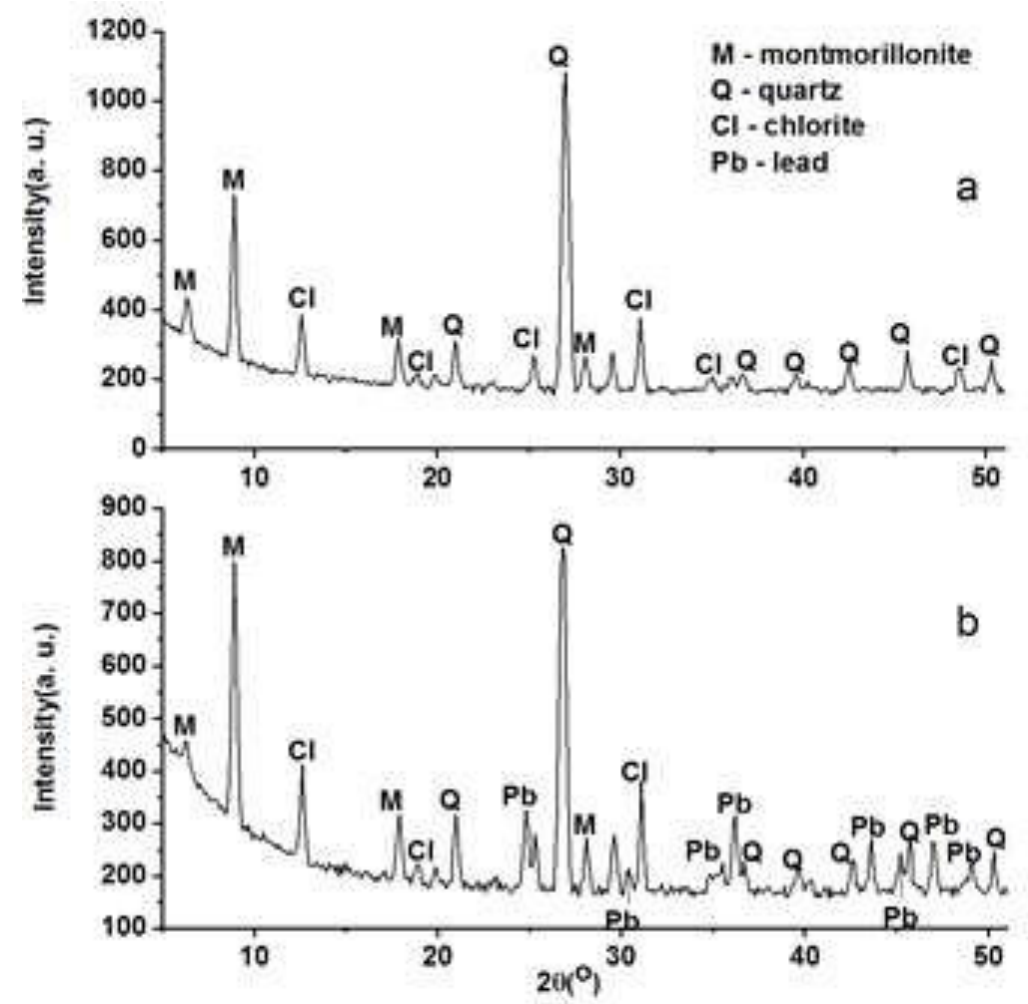

Fig. 1. XRD patterns: (a) natural bentonite, (b) MTB after $\mathrm{Pb}^{2+}$ adsorption 
during adsorption. This is supported by the following reasons.

The $\mathrm{pH}$ of the solution after adsorption increased from 4.7 to 6.7. This coincides with the statement that microwave processing in aqueous media causes partial destruction of silica skeleton by migration of $\mathrm{SiO}_{4}{ }^{2-}$. These ions are hydrolyzed and the $\mathrm{pH}$ value increases. In addition, the amount of free $\mathrm{OH}$-groups increases after destruction of $\mathrm{Si}-\mathrm{O}$ bonds in surficial $\equiv \mathrm{Si}-\mathrm{OH}$ groups. Consequently, it is conceivable that the adsorption of $\mathrm{Pb}^{2+}$ ions on bentonite occurs not only by the formation of Langmuir monolayer of hydrated ions but also by the spontaneous crystallization of neutral compounds (poorly soluble silicates or lead hydroxide) on the surface of the adsorbent.

According to classical heterogeneous nucleation theory, these nucleation centers should have an ideal structure for crystallization. Nanocrystals of small size ( $<300$ atoms) have a non-perfect structure compared with the those of higher size $(>1500$ atoms). The motion of atoms is chaotic in small nanocrystals; high-frequency components with a maximum at $\sim 10^{13} \mathrm{~Hz}$ (even up to $5 \cdot 10^{14} \mathrm{~Hz}$ ) are observed in their vibrational spectra for this reason [11]. That is why it is reasonable to assume that favorable conditions are created for the formation of nucleation centers on the surface of inert alumosilicate phase (amorphous material) due to microwave processing at certain frequency in the presence of polar water molecules. Kinetics of their
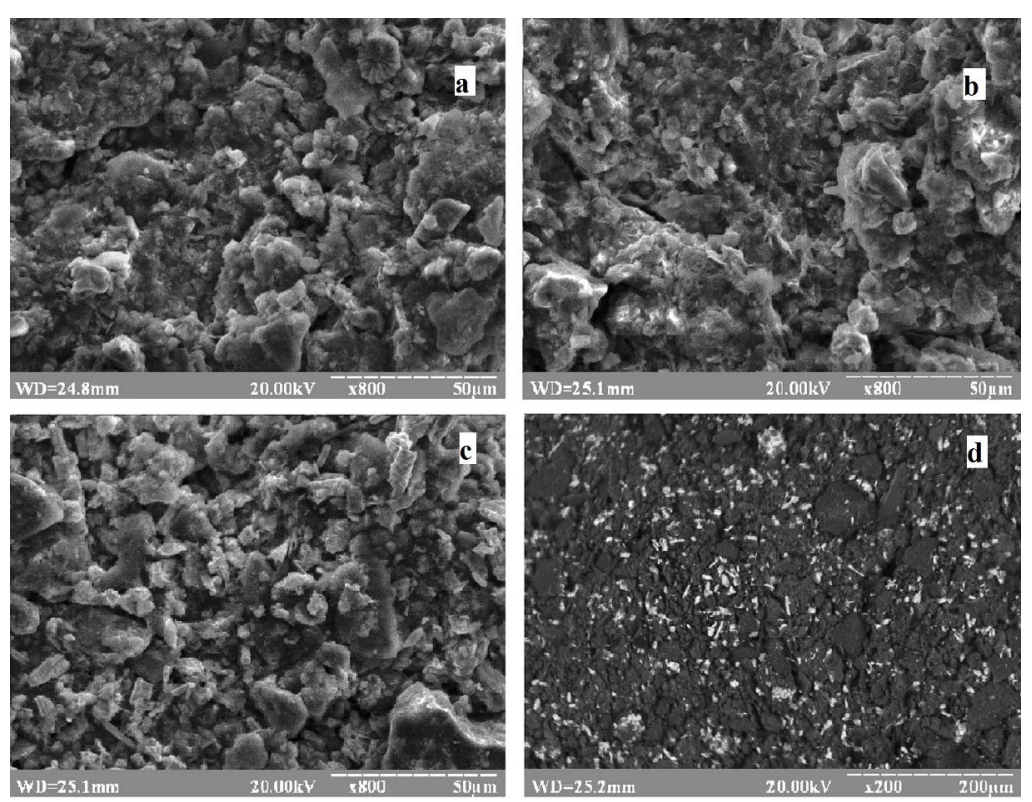

Fig. 2. SEM images: a - natural bentonite; $\mathrm{b}-\mathrm{MTB}$ before $\mathrm{Pb}$ adsorption; $\mathrm{c}-\mathrm{MTB}$ after $\mathrm{Pb}^{2+}$ adsorption; $\mathrm{d}-\mathrm{MTB}$ after $\mathrm{Pb}$ adsorption dark-field microscopy technique growth is already unclear, it is advisable to investigate in further studies.

The SEM images of natural and microwave treated bentonite (Fig. 2,a, 2,b) revealed significant changes in their surface morphology. The surface of raw material can be described as grain-like particles with fluffy protrusions and fringed edges. Microwave treated bentonite shows a much more porous and layered internal structure. The quantity of microand mesopores increases; the fringes on the edges come off. Figure 2,c and d displays SEM images of MTB samples after adsorption of $\mathrm{Pb}^{2+}$ ions from solution. A lot of new crystals appeared in the pores. Well-facetted crystals are clearly visible on the smooth grain background. Dark-field microscopy technique gives an opportunity to see placers of bright crystals (heavy metals) on the dark background (alumosilicates).

Elemental analysis according to the EDX spectra showed that $\mathrm{Si}, \mathrm{Al}, \mathrm{K}$, and $\mathrm{Fe}$ were the main elements in natural bentonite (Fig. 3, a, Table 1). There are no significant changes after sorption according to the local EDX analysis of dark field that is most probably an alumosilicate (Fig. 3,b). Figure 3, c shows EDX spectrum of light field of the sample, it is seen that lead is here a prevailing element (up to 82\%). Most probably, these were the crystals of plumbophyllite. According to EDX data, the content of lead was increased up to $16-18 \%$ for MTB surface after sorption. This corresponded to the content of $\mathrm{Pb}^{2+}$ equal to $140 \pm 10 \mathrm{mg} / \mathrm{g}$ (according 

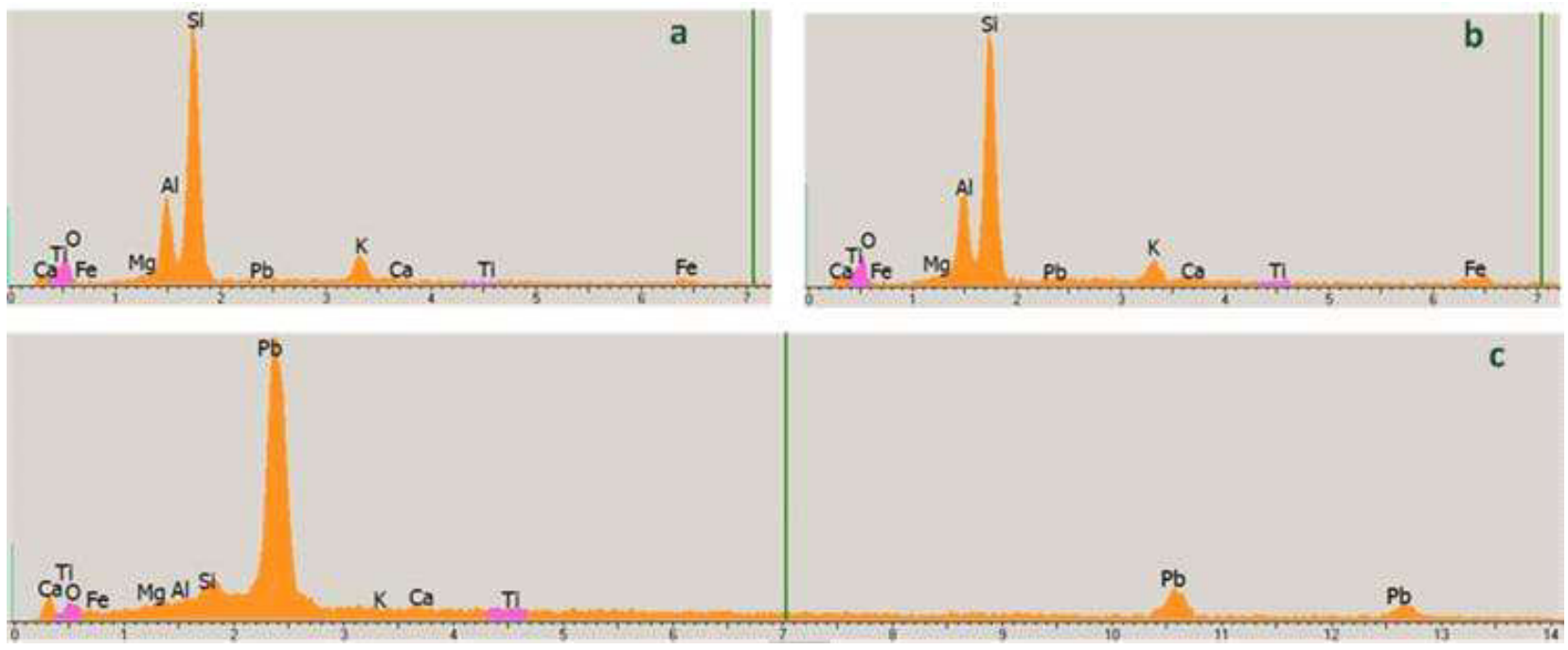

Fig. 3. EDS spectra: a - natural bentonite; b - MTB after sorption (dark field); c - MTB after sorption (light field)

Table 1

Elemental composition of the samples determined by means of EDX analysis

\begin{tabular}{l|c|c|c|c|c|c|c}
\hline \multirow{2}{*}{ Sample } & \multicolumn{7}{|c}{ Elemental composition, \% } \\
\cline { 2 - 9 } & $\mathrm{Mg}$ & $\mathrm{Al}$ & $\mathrm{Si}$ & $\mathrm{K}$ & $\mathrm{Fe}$ & $\mathrm{Pb}$ & Others \\
\hline Natural bentonite & 0.88 & 12.2 & 50.98 & 4.16 & 1.53 & $<\mathrm{DL}^{*}$ & $\mathrm{Ca}, \mathrm{Ti}$ \\
\hline MTB after sorption (dark field) & 1.51 & 26.19 & 42.57 & 9.78 & 1.40 & 0.9 & $\mathrm{Ca}, \mathrm{Ti}$ \\
\hline MTB after sorption (light field) & 0.14 & 0.27 & 0.38 & $<\mathrm{DL}$ & 0.24 & 82.0 & $\mathrm{Ca}, \mathrm{Ti}$ \\
\hline
\end{tabular}

Note: * - DL stands for detection limit.

to the data of atomic absorption spectroscopy).

Hence, the sorption of $\mathrm{Pb}^{2+}$ occurs mainly not in pores or in monomolecular layer on the surface of the bentonite, but it is followed by microcrystals formation.

Sharp multiple bands at 3648 to $3850 \mathrm{~cm}^{-1}$ are observed in the FT-IR spectra of raw bentonite before and after lead adsorption (Fig. 4); they can be assigned to $\mathrm{Al}-\mathrm{OH}-\mathrm{Al}$ in the mineral [12]. A single and very sharp band observed at $3628 \mathrm{~cm}^{-1}$ is assigned to the $\mathrm{O}-\mathrm{H}$ stretching vibration of structural $\mathrm{OH}$ groups coordinated to the cations in octahedral sheet [13]. This band followed by a broad band at $3300 \mathrm{~cm}^{-1}$ that is related to the $\mathrm{O}-\mathrm{H}$ stretching vibration of interlayer water molecules [13,14]. Three well-defined peaks (a clear and wide peak at $1418 \mathrm{~cm}^{-1}$ and two weak but narrow peaks at $873 \mathrm{~cm}^{-1}$ and $694 \mathrm{~cm}^{-1}$ ) in case of raw bentonite indicate the presence of $\mathrm{CaCO}_{3}$ [14]. As they disappear from the spectra after microwave treatment, we assume that irradiation leads to the decomposition of carbonate. A broad band with a peak at about $980 \mathrm{~cm}^{-1}$ is attributed to the $\mathrm{Si}-\mathrm{O}$ stretching vibration in Al-rich material. Three sharp peaks at 796, 777 and $694 \mathrm{~cm}^{-1}$ seen in both spectra are related to quartz [15]. There are three new peaks that appear after $\mathrm{Pb}^{2+}$ adsorption. Distinct narrow peaks at 1395 , 836 and $676 \mathrm{~cm}^{-1}$ can be attributed to $2 \mathrm{PbCO}_{3} \cdot \mathrm{Pb}(\mathrm{OH})_{2}$; thus the presence of lead in the adsorbent is indubitable.

\section{Adsorption of lead (II) ions}

The adsorption capacity of natural and microwave treated bentonite was evaluated by fitting the data with the adsorption isotherms. The isotherms provide the information about both the maximal adsorption capacity and the adsorption mechanism. The experimental results were fitted by Langmuir, Freundlich, Redlich-Peterson, Toth and LangmuirFreundlich isotherms. Figures 5 and 6 illustrate the experimental data of $\mathrm{Pb}^{2+}$ adsorption on natural and microwave treated bentonite and their fitting to the theoretical models. Table 2 presents the isotherms parameters for natural bentonite.

The adsorption model that well fits the adsorption data was selected by the minimal out-ofsample ARE value. Although these models provided the best $R^{2}$ values, the determination coefficient is only the secondary metric for the model selection.

The experimental data on $\mathrm{Pb}(\mathrm{II})$ adsorption on natural bentonite resembles a classical adsorption 




Fig. 4. FT-IR spectra: $\mathrm{a}-$ natural bentonite; $\mathrm{b}-\mathrm{MTB}$ after Pb adsorption

plot with the fast increase in adsorption capacity at low equilibrium level and gradual saturation which is displayed by a plateau (Fig. 5). However, when the experimental data are fitted to the isotherms, only Langmuir and Langmuir-Freundlich provide a reasonable fit. On the contrary, Toth, Freundlich, and Redlich-Peterson models are not fitted well. In Freundlich isotherm, n-parameter is close to 1 , which converts it into Henry model. The similar situation is observed for Toth isotherm. As for RedlichPeterson isotherm, the procedure optimizes nparameter to zero, and a to 1 . The resulting plots for Toth, Freundlich and Redlich-Peterson models have no physical meaning and therefore are not shown in Fig. 5. Langmuir-Freundlich model revealed the fit to the experimental data of $\mathrm{Pb}$ adsorption on natural bentonite. The adsorption of $\mathrm{Pb}^{2+}$ on natural bentonite is likely to follow the typical ion-exchange mechanism with formation of multilayers inside the available basal interlayer spacing.

The adsorption on MTB sample (Fig. 6) is a classic L-type plot with a strict plateau [6]. The data are well fitted with all the isotherms, except of the Freundlich one. The best-fit was obtained for the Langmuir-Freundlich model. This fact indicates that the adsorption occurs on heterogeneous sites, and thus may involve physical and chemical adsorption as well as surface precipitation.

A higher value of $\mathrm{K}$ coefficient in Langmuir isotherm reveals higher affinity of lead(II) to the 


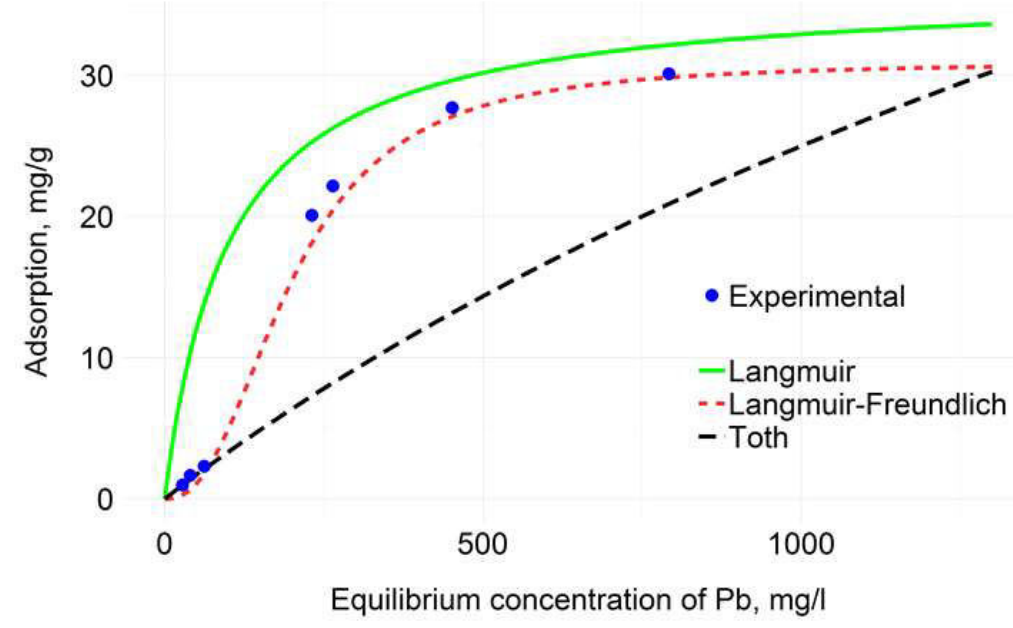

Fig. 5. Isotherms of lead(II) adsorption on natural bentonite

Table 2

Isotherm parameters for the removal of $\mathrm{Pb}^{2+}$ from simulated wastewater on natural and microwave treated bentonite

\begin{tabular}{|c|c|c|c|c|c|c|}
\hline \multirow{2}{*}{ Isotherm } & Isotherm parameters values & ARE & $\mathrm{R}^{2}$ & Isotherm parameters values & ARE & $\mathrm{R}^{2}$ \\
\hline & \multicolumn{3}{|c|}{ Natural bentonite } & \multicolumn{3}{|c|}{ Microwave treated bentonite } \\
\hline \multicolumn{7}{|c|}{ Langmuir isotherm } \\
\hline $\mathrm{q}_{\mathrm{e}}$ & 36.2 & \multirow{2}{*}{$\begin{array}{c}37.7 \\
(20.0)\end{array}$} & \multirow{2}{*}{0.82} & 120.2 & \multirow{2}{*}{$\begin{array}{c}18.2 \\
(17.5) \\
\end{array}$} & \multirow{2}{*}{0.92} \\
\hline $\mathrm{K}$ & 0.001 & & & 0.02 & & \\
\hline \multicolumn{7}{|c|}{ Freundlich isotherm } \\
\hline $\mathrm{K}$ & 0.04 & \multirow{2}{*}{$\begin{array}{c}4.7 \\
(5.8) \\
\end{array}$} & \multirow{2}{*}{0.87} & 2.78 & \multirow{2}{*}{$\begin{array}{c}23.6 \\
(53.7) \\
\end{array}$} & \multirow{2}{*}{0.81} \\
\hline $\mathrm{n}$ & 0.99 & & & 1.47 & & \\
\hline \multicolumn{7}{|c|}{ Redlich-Peterson isotherm } \\
\hline $\mathrm{n}$ & 0 & \multirow{3}{*}{$\begin{array}{c}22.9 \\
(10.1)\end{array}$} & \multirow{3}{*}{0.83} & 1.16 & \multirow{3}{*}{$\begin{array}{c}18.7 \\
(23.9)\end{array}$} & \multirow{3}{*}{0.97} \\
\hline $\mathrm{a}$ & 0.83 & & & 0.01 & & \\
\hline $\mathrm{K}$ & 0.07 & & & 2.12 & & \\
\hline \multicolumn{7}{|c|}{ Toth isotherm } \\
\hline $\mathrm{q}_{\mathrm{e}}$ & 35.12 & \multirow{3}{*}{$\begin{array}{c}23.2 \\
(18.2)\end{array}$} & \multirow{3}{*}{0.77} & 120.3 & \multirow{3}{*}{$\begin{array}{c}16.2 \\
(37.6)\end{array}$} & \multirow{3}{*}{0.90} \\
\hline $\mathrm{a}$ & 0.001 & & & 0.01 & & \\
\hline $\mathrm{n}$ & 0.84 & & & 0.98 & & \\
\hline \multicolumn{7}{|c|}{ Langmuir-Freundlich isotherm } \\
\hline $\mathrm{q}_{\mathrm{e}}$ & 30.95 & \multirow{3}{*}{$\begin{array}{c}8.2 \\
(2.0)\end{array}$} & \multirow{3}{*}{0.99} & 114.7 & \multirow{3}{*}{$\begin{array}{l}22.3 \\
(8.0)\end{array}$} & \multirow{3}{*}{0.99} \\
\hline $\mathrm{K}$ & 0.005 & & & 0.03 & & \\
\hline $\mathrm{n}$ & 2.39 & & & 1.38 & & \\
\hline
\end{tabular}

surface of MTB sample that on the natural bentonite. A high value of Freundlich n-coefficient indicates relatively strong interaction between the surface of adsorbent and ions. However, an increase in the coefficient for the modified sample indicates reduction of the interaction. Hence, an increase in the adsorption capacity cannot be attributed only to physical adsorption. It should also be noted that the isotherms data indicate that the prevalent mechanism responsible for adsorption of lead MTB sample is surface-induced co-precipitation of lead in the form of plumbophyllite.

The adsorption isotherms allow determining the maximal adsorption capacities, which are $30.95 \mathrm{mg} / \mathrm{g}$ and $114.7 \mathrm{mg} / \mathrm{g}$ for natural and MTB samples, respectively. The stimulated sample reveals significantly higher capacity than those of the natural one and given in literature for montmorillonite-like minerals [8]. Although the MTB sample showed the capacity that is considerably superior to natural sample, this is not an abnormal value. Uddin [8] reported the following values of $\mathrm{Pb}^{2+}$ uptake by clay minerals: $121.95 \mathrm{mg} / \mathrm{g}, 109.2 \mathrm{mg} / \mathrm{g}, 110 \mathrm{mg} / \mathrm{g}$ and $110 \mathrm{mg} / \mathrm{g}$ for sodic-montmorillonite, goethite, aminefunctionalized bentonite and treated bentonite, respectively. However, some works give smaller 


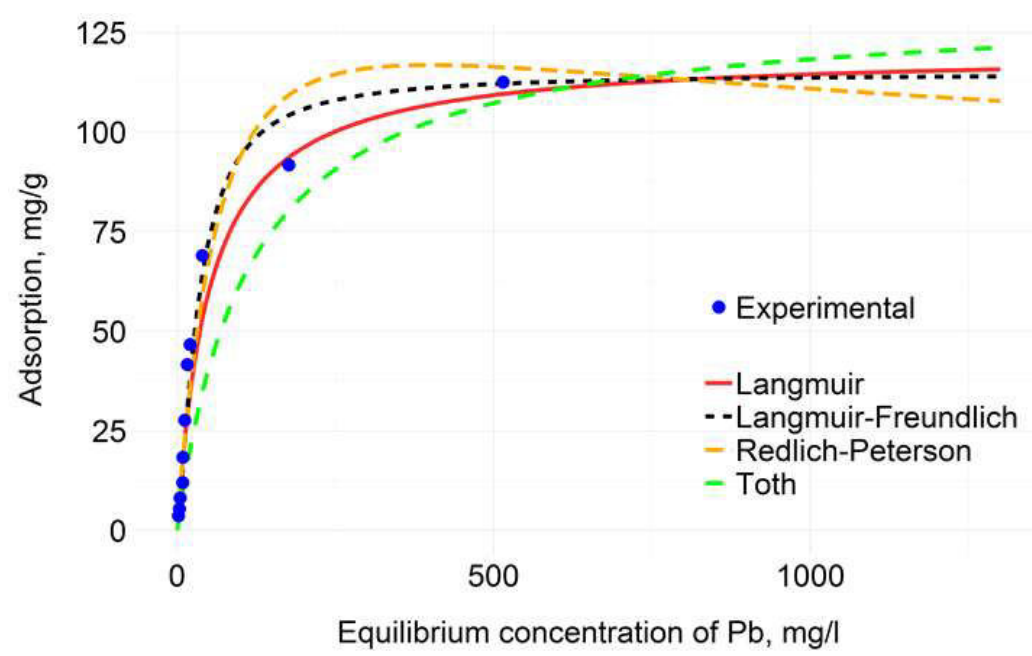

Fig. 6. Isotherms of lead adsorption on MTB

values: $0.5-5 \mathrm{mg} / \mathrm{g}[1,8]$.

The literature data indicate that MTB sample reveals a high adsorption capacity towards lead(II), and thus it is a promising material for wastewater purification. The microwave stimulation is advantageous compared to chemical modification because it does not require the additional reagents and installation of additional stage for the treatment.

\section{Conclusions}

The microwave-treated bentonite has an enhanced adsorption capacity towards lead(II) ions due to improvement in its pore structure. It also shows some peculiarities related to the adsorption mechanism. The adsorption study indicates that Langmuir-Freundlich isotherm appropriately fits the adsorption on natural and MTB samples. However, the maximal adsorption capacities are significantly different: $30.95 \mathrm{mg} / \mathrm{g}$ and $114.7 \mathrm{mg} / \mathrm{g}$ for natural and MTB samples, respectively. X-ray diffraction analysis of MTB sample after adsorption indicates the formation of microcrystals of individual compound of poorly soluble polysilicate plumbophyllite. The adsorption on MTB sample occurs not only in pores or in monomolecular layer on the bentonite surface. The prevalent mechanism is a surface-induced co-precipitation of lead(II) in the form of plumbophyllite microcrystals. This fact is confirmed by an increase in the lead content on MTB sample surface after sorption (up to 16-18\%).

\section{REFERENCES}

1. Multi-component adsorption of $\mathrm{Pb}(\mathrm{II}), \mathrm{Cd}(\mathrm{II})$, and $\mathrm{Ni}(\mathrm{II})$ onto Egyptian Na-activated bentonite; equilibrium, kinetics, thermodynamics, and application for seawater desalination /
Taha A.A., Shreadah Mohamed A., Ahmed A.M., Heiba H.F. // J. Environ. Chem. Eng. - 2016. - Vol.4. - No. 1. - P.1166-1180.

2. Komadel P., Madejova J. Acid activation of clay minerals // Developments in clay science: handbook of clay science. Elsevier. - 2013. - Vol.5. -P.385-409.

3. Van Oss C.J., Giese R.F. Surface modification of clays and related materials // J. Dispersion Sci. Technol. - 2003. Vol.24. - No. 3-4. - P.363-376.

4. About using microwave irradiation in competitive adsorption processes / Legras B., Polaert I., Thomas M., Estel L. // Appl. Therm. Eng. - 2013. - Vol.57. - No. 1-2. - P.164-171.

5. Kinniburgh D.G. General purpose adsorption isotherms // Environ. Sci. Technol. - 1986. - Vol.20. - No. 9. - P.895-904.

6. Giles C.H., Smith D., Huitson A. A general treatment and classification of the solute adsorption isotherm. Part I. Theoretical // J. Colloid Interface Sci. - 1974. - Vol.47. No. 3. - P.755-765.

7. Ratkowsky D. Handbook of nonlinear regression models. - New York: Marcel Dekker Inc., 1990. - 241 p.

8. Uddin M.K. A review on the adsorption of heavy metals by clay minerals, with special focus on the past decade // Chem. Eng. J. - 2017. - Vol.308. - P.438-462.

9. Kontsur A., Sysa L., Petrova M. Investigation of copper adsorption on natural and microwave-treated bentonite // East. Eur. J. Enterprise Technol. - 2017. - Vol.6. - No. 90. - P.2632.

10. Kampf A.R., Rossman G.R., Housley R.M. Plumbophyllite, a new species from the Blue Bell claims near Baker, San Bernardino County, California // Am. Mineral. 2009. - Vol.94. - No. 8-9. - P.1198-1204.

11. Ovrutsky A.M., Prokhoda O.S. Vynyknennya i rist tsentriv krystalizatsii v amorfniy phazi // Phizyka i Khimiya Tverdogo Tila. - 2010. - Vol.11. - No. 2. - P.391-394.

12. Spectroscopic characterization of bentonite / Ravindra Reddy T., Kaneko S., Endo T., Lakshmi Reddy S. // J. Lasers Opt. Photonics. - 2017. - Vol.4. - Art. No. 171. 
13. Observation of characteristic IR band assignable to dimerized copper ions in montmorillonite / Tanaka M., Itadani A., Abe T., Taguchi H., Nagao M. // J. Colloid Interface Sci. 2007. - Vol.308. - P.285-288.

14. Preparation of ultrafine calcium carbonate particles with micropore dispersion method / Wu G., Wang Y., Zhu S., Wang J. // Powder Technol. - 2007. - Vol.172. - P.82-88.

15. ATR-FT-IR spectral collection of conservation materials in the extended region of $4000-80 \mathrm{~cm}^{-1} /$ Vahur S., Teearu A., Peets P., Joosu L., Leito I. // Anal. Bioanal. Chem. - 2016. Vol.408. - No. 13. - P.3373-3379.

Received 05.03.2019

\section{НВЧ-МОДИФІКОВАНІ БЕНТОНІТИ ДЛЯ ВИЛУЧЕННЯ ПЛЮМБУМУ ЗІ СТІЧНИХ ВОД}

\section{Л.В. Сиса, К.В. Степова, М.А. Петрова, А.З. Концур}

Глинисті матеріали є перспективними адсорбентами для видалення різних забруднюючих речовин із стічних вод. Метою даної роботи є дослідження змін структури та адсорбційної здатності обробленого надвисокочастотним (НВЧ) випромінюванням бентоніту після адсорбції Плюмбуму. Структурні дослідження НВЧ-модифікованого зразка показали, що відбувається часткове руйнування кремнієвого скелета, а при НВЧ оброблення формуються нові центри кристалізації. Адсорбція $\mathrm{Pb}^{2+}$ на природному бентоніті відбувається на гетерогенних адсорбційних центрах, тоді як вилучення Плюмбуму під дією НВЧ випромінювання супроводжується утворенням мікрокристалів плюмбофіліту. Було здійснено серії експериментів поглинання Плюмбуму на природному та НВЧ-модифікованому бентонітах. Інтерпретацію отриманих результатів здійснювали в рамках моделей адсорбиії Ленгмюра, Фрейндліха, Тота, Редліха-Петерсона та Ленгмюра-Фрейндліха. НВЧ-модифіковані зразки показують значно більшу ефективність щодо Плюмбуму, їх максимальна адсорбційна здатність складає 14,7 мг/2, порівняно з 31 мг/г для природного зразка.

Ключові слова: модифіковані глини, бентоніт, НВЧоброблення, ізотерми адсорбції, нелінійне моделювання, вилучення Плюмбуму.

\section{MICROWAVE-TREATED BENTONITE FOR REMOVAL OF LEAD FROM WASTEWATER}

L.V. Sysa, K.V. Stepova *, M.A. Petrova, A.Z. Kontsur

Lviv State University of Life Safety, Lviv, Ukraine

*e-mail: katyastepova@gmail.com

Clay-based materials are promising adsorbents for removal of various pollutants from wastewater. This work is aimed to study the changes in structure and adsorption capacity of microwave-treated bentonite after adsorption of lead(II) ions. The structural investigation of the microwave-treated sample reveals that a partial destruction of silica skeleton takes place, and new surface nucleation centers are formed during microwave processing. The adsorption of $\mathrm{Pb}^{2+}$ on natural bentonite occurs on heterogeneous adsorption sites, whereas the removal of lead on microwave-treated sample is accompanied by the formation of plumbophyllite microcrystals. The natural and microwave-treated adsorbents were tested for lead adsorption in batch experiments. The results were fitted according to Langmuir, Freundlich, Toth, Redlich-Peterson, and Langmuir-Freundlich isotherms of adsorption. The microwave-treated samples revealed substantially higher efficiency towards the removal of lead, their maximal adsorption capacity was $114.7 \mathrm{mg} \mathrm{g}^{-1}$, whereas natural samples showed only $31 \mathrm{mg} \mathrm{g}^{-1}$.

Keywords: modified clays; bentonite; microwave treatment; adsorption isotherms; non-linear modeling; lead removal.

\section{REFERENCES}

1. Taha A.A., Shreadah M.A., Ahmed A.M., Heiba H.F. Multi-component adsorption of $\mathrm{Pb}(\mathrm{II}), \mathrm{Cd}(\mathrm{II})$, and $\mathrm{Ni}$ (II) onto Egyptian Na-activated bentonite; equilibrium, kinetics, thermodynamics, and application for seawater desalination. Journal of Environmental Chemical Engineering, 2016, vol. 4, pp. 1166-1180.

2. Komadel P., Madejova J. Acid activation of clay minerals. In: Developments in clay science: handbook of clay science, F. Bergaya, G. Lagaly (eds.), Elsevier, 2013, vol. 5, pp. 385-409.

3. Van Oss C.J., Giese R.F. Surface modification of clays and related materials. Journal of Dispersion Science and Technology, 2003, vol. 24, pp. 363-376.

4. Legras B., Polaert I., Thomas M., Estel L. About using microwave irradiation in competitive adsorption processes. Applied Thermal Engineering, 2013, vol. 57, pp. 164-171.

5. Kinniburgh D.G. General purpose adsorption isotherms. Environmental Science \& Technology, 1986, vol. 20, pp. 895-904.

6. Giles C.H., Smith D., Huitson A. A general treatment and classification of the solute adsorption isotherm. Part I. Theoretical. Journal of Colloid and Interface Science, 1974, vol. 47 , pp. $755-765$

7. Ratkowsky D., Handbook of nonlinear regression models. Marcel Dekker Inc., New York, 1990. 241 p.

8. Uddin M.K. A review on the adsorption of heavy metals by clay minerals, with special focus on the past decade. Chemical Engineering Journal, 2017, vol. 308, pp. 438-462.

9. Kontsur A., Sysa L., Petrova M. Investigation of copper adsorption on natural and microwave-treated bentonite. EasternEuropean Journal of Enterprise Technologies, 2017, vol. 6, no. 90, pp. 26-32.

10. Kampf A.R., Rossman G.R., Housley R.M. Plumbophyllite, a new species from the Blue Bell claims near Baker, San Bernardino County, California. American Mineralogist, 2009, vol. 94, pp. 1198-1204.

11. Ovrutsky A.M., Prokhoda O.S. Vynyknennya i rist tsentriv krystalizatsii $v$ amorfnii phazi [Appearance and growth of centers of crystallization in the amorphous phase]. Phizyka $i$ Khimiya Tverdogo Tila, 2010, vol. 11, no. 2, pp. 391-394. (in Ukrainian).

12. Ravindra Reddy T., Kaneko S., Endo T., Lakshmi Reddy S. Spectroscopic characterization of bentonite. Journal of Lasers, Optics \& Photonics, 2017, vol. 4, article no. 171.

13. Tanaka M., Itadani A., Abe T., Taguchi H., Nagao M. Observation of characteristic IR band assignable to dimerized copper ions in montmorillonite. Journal of Colloid and Interface Science, 2007, vol. 308, pp. 285-288.

14. Wu G., Wang Y., Zhu S., Wang J. Preparation of ultrafine calcium carbonate particles with micropore dispersion method. Powder Technology, 2007, vol. 172, pp. 82-88.

15. Vahur S., Teearu A., Peets P., Joosu L., Leito I. ATRFT-IR spectral collection of conservation materials in the extended region of 4000-80 $\mathrm{cm}^{-1}$. Analytical and Bioanalytical Chemistry, 2016, vol. 408, pp. 3373-3379. 